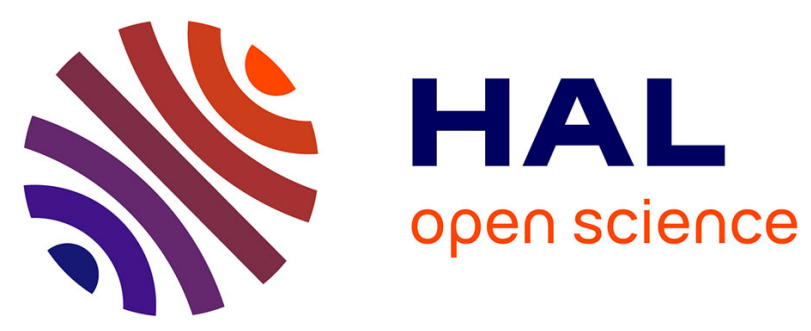

\title{
RNF170-related hereditary spastic paraplegia: confirmation by a novel mutation
}

Jean-madeleine de Sainte Agathe, Sandra Mercier, Jean-yves Mahé, Yann

Péréon, Julien Buratti, Laurène Tissier, Bophara Kol, Samia Ait Said, Éric

Leguern, Guillaume Banneau, et al.

\section{To cite this version:}

Jean-madeleine de Sainte Agathe, Sandra Mercier, Jean-yves Mahé, Yann Péréon, Julien Buratti, et al.. RNF170-related hereditary spastic paraplegia: confirmation by a novel mutation. Movement Disorders, In press, 10.1002/mds.28371 . hal-03059847

\section{HAL Id: hal-03059847 https://hal.science/hal-03059847}

Submitted on 13 Dec 2020

HAL is a multi-disciplinary open access archive for the deposit and dissemination of scientific research documents, whether they are published or not. The documents may come from teaching and research institutions in France or abroad, or from public or private research centers.
L'archive ouverte pluridisciplinaire HAL, est destinée au dépôt et à la diffusion de documents scientifiques de niveau recherche, publiés ou non, émanant des établissements d'enseignement et de recherche français ou étrangers, des laboratoires publics ou privés. 
J.M. de Sainte Agathe, $\mathrm{MS}^{1}$, S. Mercier, MD, $\mathrm{PhD}^{2,3}$, J.Y. Mahé, $\mathrm{MD}^{3,4}$, Y. Péréon, MD, $\mathrm{PhD}^{3,5}$, J. Buratti, MS ${ }^{1}$, L. Tissier ${ }^{1}$, B. $\mathrm{Kol}^{1}$, S. Ait Said, MS ${ }^{1}$, E. Leguern, MD, $\mathrm{PhD}^{1,6}, \mathrm{G}$. Banneau, $\mathrm{PhD}^{1}$, G. Stevanin, $\mathrm{PhD}^{6,7}$

1 Assistance Publique - Hôpitaux de Paris, GH Sorbonne Université, Département de génétique, Hôpital Pitié-Salpêtrière.

2 CHU Nantes, Service de génétique médicale, Nantes, France.

3 Centre de Référence des Maladies Neuromusculaires, AOC, Hôtel-Dieu, Nantes, F-44000, France.

4 Établissement de Santé pour Enfants et Adolescents de la région Nantaise, Nantes, France.

5 CHU de Nantes, Laboratoire d'Explorations Fonctionnelles, Nantes, F-44000, France.

6 Institut du Cerveau, Sorbonne université (INSERM 1127, CNRS 7225), Paris, France.

7 Équipe de neurogénétique, École Pratique des Hautes Etudes (EPHE), PSL Research University, Paris, France.

Background:

Spastic paraparesis and biallelic variants functionally characterized as deleterious in the RNF170 gene have recently been reported by Wagner et al. ${ }^{1}$, strongly supporting the involvement of this gene in Hereditary Spastic Paraplegia (HSP).

Objectives, Methods: 
Exome sequencing were performed on 6 HSP families previously tested on HSP specific panel.

Results:

We describe here a novel HSP family with four affected members carrying a homozygous p.(Tyr114*) stop gain variant in $R N F 170$.

Conclusions:

We confirm the involvement of biallelic truncating variants in $R N F 170$ in a novel form of HSP.

This gene encodes RNF170, a ubiquitin E3 ligase belonging to the Endoplasmic Reticulum Associated protein Degradation pathway ${ }^{2}$, a cellular pathway already known to be involved in pathophysiology of HSP with ERLIN2 (SPG18) ${ }^{3}$, ARL6IP1 (SPG61), and ERLIN1 (SPG62) ${ }^{4}$. Biallelic loss-of-function variants in $R N F 170$ have been involved in a novel form of HSP with a phenotype associating early-onset HSP with optic atrophy ${ }^{1}$.

The four new patients described here are siblings of a distantly related couple from Guinea (Fig. 1). Their phenotypes (Table 1) correspond to those previously reported, except for optic atrophy which has not been explored.

This family was selected for whole exome sequencing after the negativity of genetic investigations on individual 2 with a HSP specific panel used in our diagnostic laboratory, according to Morais et al. ${ }^{5}$.

Whole exome sequencing was performed on DNA extracted from blood-derived leukocytes of the four affected individuals and their two parents using SeqCap EZ MedExome Target 
Enrichment Kit (Roche, Basel, Switzerland). Sequencing was carried out as paired-end $151 \mathrm{bp}$ reads on a NextSeq500 (Illumina, San Diego, USA). Raw data were analyzed using in-house annotation and analysis pipelines based on the hg19 human genome reference as described elsewhere ${ }^{6}$

Briefly, only non-synonymous coding and splicing variants found in the four siblings were considered. Variant filtering was performed according to the mode of transmission based on the parents' genotypes (de novo, autosomal recessive and X-linked), the frequency of the variant in the gnomAD database $(<0.01 \%$ and $<50$ heterozygous carriers or $<5$ homo/hemizygous carriers $)$ and in our in-house database of $n=866$ exomes $(<1$ homozygous occurrence).

Four candidate variants were identified through filtering in the SMIM19, SULF1, RNF170 and $R P 1$ genes. Only one ( $R N F 170$ ) was absent from the general population database, including Africans (gnomAD). The other three were two intronic variants and one missense, all with very mild in-silico prediction effects. The very rare variant in $R N F 170$ was carried by all four affected siblings and was a homozygous stop-gain variant NM_030954.3:c.342C>G; p.(Tyr114*) (see Fig. 1) in exon 5 of $R N F 170$. This variant is predicted to be degraded by the nonsense mediated decay according to the $50 \mathrm{bp}$ rule $^{8}$. Moreover, the involvement of several downstream truncating variants in this HSP phenotype (p.Ala109Asnfs*9;

p.Arg173Asnfs*49, Fig. 1B) strongly supports the pathogenic role of the p.(Tyr114*) variant.

The homogeneous clinical spectrum of this new RNF170-related HSP family is consistent with those previously described, including an early age of onset $(<5 \mathrm{y})$. The age of loss of independent walking is earlier in our family. Optical coherence tomography was not 
performed but no severe visual defect nor aggravation was detected and the eye fundus performed at the age of 12 years in individual 2 was considered normal. This new family emphasizes a possible genotype-phenotype correlation regarding the variability of cerebellar impairments found between distinct families. All four individuals in our new family are carriers of a variant probably targeted by NMD and are free of any cerebellar defect, which brings significance to the hypothesis of a toxic gain-of-function. Indeed, the presence of cerebellar defects seems to be correlated with variants probably escaping NMD (Cys102Arg and Arg173Asnfs*49, $n=6$ cases from Wagner et al) and their absence is associated with transcript deleting variants (via prohibited transcription: delEx4_7, n=1 from Wagner et al; or via NMD-targeted variants: Tyr114*, n=4 from our study).

Interestingly, the p.Ala109Asnfs*9 variant reported by Wagner et al. was described as partially escaping NMD, and although no ataxia was found in the two affected individuals, they have been reported as having a saccadic oculomotricity, suggesting a potential minor cerebellar alteration.

In conclusion, the description of this new family case confirms the involvement of bi-allelic variants in the RNF170 gene in this new autosomal recessive form of HSP. This new clinicogenetic entity is a rare form of hereditary spastic paraplegia since only one affected family was identified among the 141 HSP families of our local reference center (69 exomes, 72 NGS genes panel including $R N F 170$ ) and has not been found in a cohort of 344 recessive ataxias or in 865 other neurological cases analyzed by exome in our center.

Other case reports are needed to precisely define the clinical spectrum of this HSP entity and validate the genotype-phenotype correlations. 
Authors roles:

J.M. de Sainte Agathe, whole exome sequencing execution and analysis, writing of the first draft of the manuscript

S. Mercier, main clinical description, manuscript review and critique

J.Y. Mahé, clinical description

Y. Péréon, clinical description, manuscript review and critique

J. Buratti, informatical pipeline designer for the sequencing analysis

L. Tissier, technical sequencing adviser

B. Kol, technical sequencing adviser

S. Ait Said, research project conception and organization

É. Le Guern, research project conception and organization, manuscript review and critique

G. Banneau, research project conception and organization, manuscript review and critique

G. Stevanin, research project conception, main manuscript reviewing and critique

Financial Disclosure Statement:

The authors declare no conflict of interest.

Dr S. Mercier received research support from the AFM-Téléthon (Association Française contre les Myopathies), the Groupama Foundation and the Thellie Foundation (https://thellie.org/).

Dr G. Stévanin received financial support from the Spastic Paraplegia Foundation, the 
European Union (grant 779257 Solve-RD from the Horizon 2020 Research and Innovation

Programme, the Strumpell-Lorrain association (to GS), the Connaitre les Syndromes

cérébelleux association and the Erare program for research on Rare Diseases

(PREPARE_ATAXIA).

Pr Y. Péréon declares having being involved in an advisory boards: Avexis, PTC

Therapeutics, Alnylam, Lupin, and receiving honoraria: Novartis, Akcea, LFB, Pfizer, Sanofi.

All other authors declare no conflict of interest and all have received salary from the state as part of their public employment.

Copyright:

This work is not under any copyright and has been produced without unmentioned participation.

Acknowledgements:

The authors gratefully thank the contribution and commitment of the patients and their parents.

References:

1. Wagner, M. et al. Bi-allelic variants in RNF170 are associated with hereditary spastic paraplegia. Nat. Commun. 10, 4790 (2019). 
2. Lu, J. P., Wang, Y., Sliter, D. A., Pearce, M. M. P. \& Wojcikiewicz, R. J. H. RNF170 Protein, an Endoplasmic Reticulum Membrane Ubiquitin Ligase, Mediates Inositol 1,4,5Trisphosphate Receptor Ubiquitination and Degradation. J. Biol. Chem. 286, 24426-24433 (2011).

3. Alazami, A. M., Adly, N., Al Dhalaan, H. \& Alkuraya, F. S. A nullimorphic ERLIN2 mutation defines a complicated hereditary spastic paraplegia locus (SPG18). neurogenetics 12, 333-336 (2011).

4. Novarino, G. et al. Exome Sequencing Links Corticospinal Motor Neuron Disease to Common Neurodegenerative Disorders. Science 343, 506-511 (2014).

5. Morais, S. et al. Massive sequencing of 70 genes reveals a myriad of missing genes or mechanisms to be uncovered in hereditary spastic paraplegias. Eur. J. Hum. Genet. 25, 1217-1228 (2017).

6. Larcher, L. et al. The complete loss of function of the SMS gene results in a severe form of Snyder-Robinson syndrome. Eur. J. Med. Genet. 103777 (2019) doi:10.1016/j.ejmg.2019.103777.

7. Valdmanis, P. N. et al. A mutation in the RNF170 gene causes autosomal dominant sensory ataxia. Brain 134, 602-607 (2011).

8. Nagy, E. \& Maquat, L. E. A rule for termination-codon position within intron-containing genes: when nonsense affects RNA abundance. Trends Biochem. Sci. 23, 198-199 (1998). 
Table 1: Clinical characteristics of a new family affected by RFN170 related HSP. Moi mode of inheritance, $U L$ upper limb, $L L$ lower limb, $y$ years, $n . d$. not done. * vibration/joint position/surface/temperature.

\begin{tabular}{|c|c|c|c|c|}
\hline ID & 1 & 2 & 3 & 4 \\
\hline \multirow{2}{*}{ Variant } & c. $342 \mathrm{C}>\mathrm{G}$ & c. $342 \mathrm{C}>\mathrm{G}$ & c. $342 \mathrm{C}>\mathrm{G}$ & c. $342 \mathrm{C}>\mathrm{G}$ \\
\hline & Tyr114* (hom) & Tyr114* (hom) & Tyr114* (hom) & Tyr114* (hom) \\
\hline moi/gender & $\mathrm{AR} / \mathrm{M}$ & $\mathrm{AR} / \mathrm{F}$ & $\mathrm{AR} / \mathrm{F}$ & $\mathrm{AR} / \mathrm{M}$ \\
\hline Age at onset (y) & 3 & 3 & 3 & 3 \\
\hline Age at exam (y) & 20 & 17 & 13 & 10 \\
\hline $\begin{array}{l}\text { Age at loss of } \\
\text { independent walking }\end{array}$ & 10 & 10 & 10 & still walking \\
\hline $\begin{array}{l}\text { Delayed motor } \\
\text { development }\end{array}$ & - & - & - & - \\
\hline Cognitive deficits & - & - & - & - \\
\hline Visual system & $\begin{array}{l}\text { refractive } \\
\text { anomaly }\end{array}$ & $\begin{array}{l}\text { refractive anoma } \\
\text { (normal eye } \\
\text { fundus at } 12 \mathrm{y} \text { ) }\end{array}$ & $\begin{array}{l}\text { refractive } \\
\text { anomaly }\end{array}$ & $\begin{array}{l}\text { refractive } \\
\text { anomaly }\end{array}$ \\
\hline $\begin{array}{l}\text { Oculomotor } \\
\text { abnormalities }\end{array}$ & - & - & - & - \\
\hline Dysarthria/ dysphagia & $-1-$ & $-1-$ & $-1-$ & $-1-$ \\
\hline UL/LL spasticity & $+/+$ & $+/+$ & $+/+$ & $+/+$ \\
\hline UL/LL tendon reflexes & Brisk/brisk & Brisk/brisk & brisk/brisk & brisk/brisk \\
\hline UL/LL weakness & $-/+($ proximal $)$ & $-/+$ (proximal) & $-/+($ distal $)$ & $-/+($ distal $)$ \\
\hline
\end{tabular}




\begin{tabular}{|c|c|c|c|c|}
\hline ID & 1 & 2 & 3 & 4 \\
\hline Muscle atrophy & $+(\mathrm{LL}$, severe $)$ & $+(\mathrm{LL}$, severe $)$ & $+(\mathrm{LL}$, severe $)$ & $+(\mathrm{LL}$, severe $)$ \\
\hline $\begin{array}{l}\text { Extensor plantar } \\
\text { response }\end{array}$ & - & mild & + & - \\
\hline Sensory deficits* & n.d. & n.d. & n.d. & n.d. \\
\hline Ataxia & - & - & - & - \\
\hline $\begin{array}{l}\text { Extrapyramidal } \\
\text { involvement }\end{array}$ & - & - & - & - \\
\hline $\begin{array}{l}\text { Urinary/fecal urgency } \\
\text { or incontinence }\end{array}$ & $-1-$ & $-1-$ & $+/-$ & $-1-$ \\
\hline $\begin{array}{l}\text { Nerve conduction } \\
\text { studies }\end{array}$ & n.d. & normal & n.d. & n.d. \\
\hline $\begin{array}{l}\text { Motor evoked } \\
\text { potentials }\end{array}$ & n.d. & $\begin{array}{l}\text { delayed LL } \\
\text { pyramidal } \\
\text { response }\end{array}$ & n.d. & n.d. \\
\hline $\begin{array}{l}\text { Sensory evoked } \\
\text { potentials }\end{array}$ & n.d. & n.d. & n.d. & n.d. \\
\hline $\begin{array}{l}\text { Visually evoked } \\
\text { potentials }\end{array}$ & n.d. & n.d. & n.d. & n.d. \\
\hline MRI & n.d. & $\begin{array}{l}\text { Cranium and } \\
\text { cervical spine } \\
\text { normal }\end{array}$ & n.d. & n.d. \\
\hline
\end{tabular}


Fig. 1: Above: pedigree of the family. Individuals who have had their exome sequenced are highlighted in blue. Genotypes are indicated by a star and a dash, respectively p.(Tyr114*) and p.Tyr114. Below: mutational landscape of phenotypes related to $R N F 170$ (NM_030954.3). In grey: heterozygous founder missense implicated in autosomal dominant sensory ataxia ${ }^{7}$. In black: homozygous variants involved in HSP by Wagner et al. ${ }^{1}$ and by this article (in bold). The lines indicate the location of the premature stop codon (e. g. the Arg173Asnfs*49 line indicates the Glu222 position). In orange: RING domain.
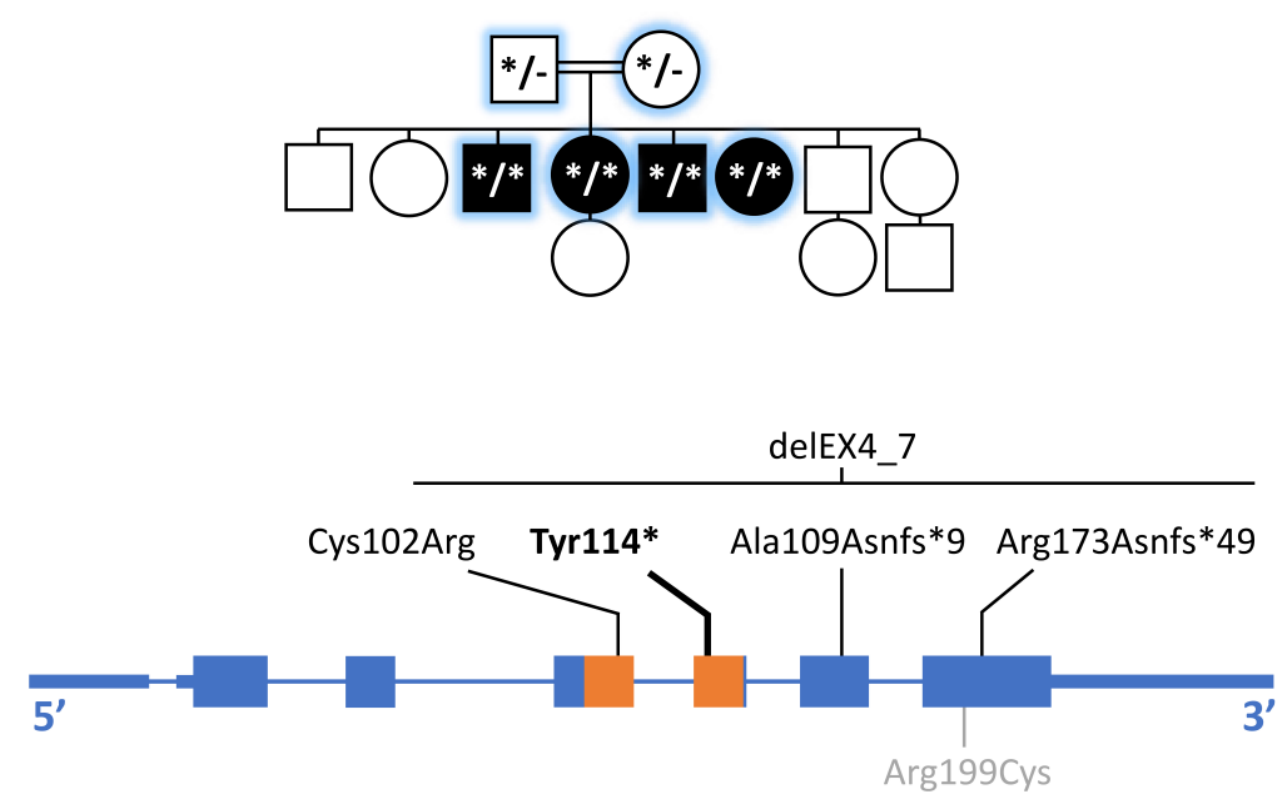